Acta Regionalia et Environmentalica 2

Nitra, Slovaca Universitas Agriculturae Nitriae, 2017, pp. 45-51

\title{
THE CULTIVATION OF FAST-GROWING TREES ON AGRICULTURAL LAND IN SLOVAKIA AND CZECHIA: LEGAL COMPARISON
}

\author{
Ján GADUŠ*, Ina MELIŠKOVÁ, Ol'ga ROHÁČIKOVÁ \\ Slovak University of Agriculture in Nitra, Slovak Republic
}

\begin{abstract}
The paper analyses the legal regulation of the cultivation of fast-growing trees on agricultural land in Slovakia and Czechia. The focus is on the differences in the legislation of the two countries, the application of the regulations of cultivation of fast-growing trees in practice, the level of protection of agricultural land, and the support system for the cultivation of fast-growing trees. Comparison of national legislation dealing with the issue of planting fast-growing trees, taking into consideration the protection of agricultural land and the legislation on granting the state support has also been investigated in the context of European legislation. The procedure before the start of planting, the permission conditions for planting of fast-growing trees, the conditions and the process of support provision have been studied. The result of the documents analysis is a comprehensive comparative overview of the above-mentioned areas of legislation on the cultivation of fast-growing trees in Slovakia and Czechia and the identification of differences, benefits and practical impacts on the cultivation of fast-growing trees.
\end{abstract}

Keywords: fast-growing trees; agricultural land protection; agricultural land; legal regulation

The development of "green energy" production has resulted, besides others, in the increased plantation of fast growing trees (FGT) for energy purposes. The cultivation of FGT is considered to be a still expanding field, with which such legal issues, as the conditions for establishing and keeping FGT plantations are connected. The Biomass Action Plan was the first document issued in the Slovak and Czechia that specifically and clearly pointed out at the efficient and effective use of biomass energy potential. Its writing has been based on the EU Biomass Action Plan approved in 2005, which consequently raised the requirement to develop national action plans in different Member States. In 2007, the budget of 90 million $€$ as a specific financial aid for energy crops was fully spent for the first time. The support program has contributed to the increased farmers' interest in producing energy crops, since the agriculture area used for their planting has been enlarged from 0.31 million of hectares in 2004 to 2.84 million of hectares in 2007 (Biomass Use Action Plan for 2008-2013). Encouraging the cultivation of biomass is not in conflict with food security, as it is one of the options how to use temporarily or permanently unused agricultural land. This also solves the problem of abandoned or unused arable land temporarily excluded from agricultural production and contaminated or devastated land found in former industrial sites, so called brownfields (Kotrla and Prčík, 2012). For the implementation of the long-term state strategy in the field of the acquisition and use of renewable energy sources, the cultivation of energy crops on agricultural land and further use of their energy is of essential importance (Marišová et al., 2015).

Plantations of FGT species with short rotations grown on arable land for the purposes of heat or combined heat and power production are seen as a very effective means to achieve increased environmental benefits. In comparison to other biomass production systems, such as oil seed rape for oil production or maize for gasification, FGT are characterized by a positive greenhouse gas balance and therefore low $\mathrm{CO}_{2}$ emission reduction costs. Furthermore, FGT has positive effects on soil ecology and water quality, and increased biodiversity (Petzold et al., 2014).

\section{Material and methods}

The aim of the paper is to analyse the current legislation on the cultivation of FGT on agricultural land in Slovakia and Czechia. The data for the monitored period 2010-2015 for the Slovak Republic and 2004-2015 for Czechia used in this paper were collected from the Electronic Yearbook of Soil Service and Land Register LPIS. The studied data in this paper cover the whole area of Slovakia and Czechia. To achieve the aim of this paper, the methods of analysis, deduction and comparison were used. Besides the legal acts of Slovakia, Czechia and the European Union in this paper, materials of the research institutes and other institutions of both republics and their statistical data were used as a source. The efficiency of cultivation of FGT in practice, the degree of protection of agricultural land and the system of support for growing FGT are evaluated. A comprehensive comparative overview of the legislation including the conditions and the process of granting support and the conditions for starting FGT planting will be discussed. 


\section{Results and discussion}

\section{Conditions for FGT planting}

\section{Czech Republic}

Basic conditions for FGT planting are stated in the Act no. 334/1992 Coll., on the Protection of Agricultural Land Fund (further just "the ALF Protection Act").

According to clause 3, section 5 of ALF Protection Act, agricultural land is divided reflecting its quality into 5 protection classes, and it is forbidden to grow FGT on the soil of the $1^{\text {st }}$ and $2^{\text {nd }}$ class of protection.

Section 6 of the Act states that agricultural land may be used for the sprout planting of trees for a maximum period of 30 years and the length of one cultivation cycle may not exceed 10 years. The owner or user is obliged by the law to remove the stems and reclaim the land within one year after the end of the use of the agricultural land for planting FGT, in order to be ready for further agricultural use. After the end of the last cultivation cycle, the agricultural land must be used in a different way for at least three years.

Section 7 of the Act also sets the obligation of the owner or user of the agricultural land to announce the start of planting trees, the beginning of the new cultivation cycle and the termination of the use of the agricultural land as a plantation of trees to ALF within 15 days from the start date of planting, the date of the beginning of the new cultivation cycle or the date of the termination of the use of agricultural land as a plantation of trees. This obligation does not apply to persons that have reported or are going to report this fact to the State Agricultural and Intervention Fund when applying for a grant according to the directly applicable European Union principles governing common rules for direct support schemes within the Common Agricultural Policy.

\section{Slovak Republic}

Conditions for FGT planting are primarily governed by Act no. 220/2004 Coll. on the Protection and Use of Agricultural Land (hereinafter referred to as "the Soil Protection Act").

In accordance with the clause 18a of the Soil Protection Act, the FGT on agricultural land stands for the vegetation of fast growing woods used for the production of wood biomass on the area larger than $1,000 \mathrm{~m}^{2}$ for a maximum of 20 years.

FGT may be planted only on agricultural land classified according to the code of eco-land evaluation unit ("ELEU") from 5 to 9 of the quality group or on contaminated land with risk substances (the Land Conservation Authority, based on the proposal of the soil service, found that the land is contaminated with risk substances that threaten the health or life of human beings and animals, and that agricultural crops cannot be used for food or feed production, or used in the food chain) or if it is classified under ELEU as 3 to 4 quality group and it is a flooded territory or land exposed to wind erosion. Information about the fact that the land is located in flooded territory or is exposed to wind erosion is provided by a District authority, a Land and forestry department after the statement of the Environmental department for the matters of the state water administration and after the municipality has expressed its opinion on the state water administration (flooded land) and the Soil Science and
Conservation Research Institute (soil buried or exposed to wind erosion).

The FGT plantations cannot be established on the land located within the $3^{\text {rd }}$ to $5^{\text {th }}$ degree of territorial protection of nature and landscape according to the clause 14 to 16 of the Act no. 543/2002 Coll. on Nature and Landscape Protection.

\section{Obligation to exclude agricultural land}

\section{Czech Republic}

Currently the cultivation of FGT is carried out without the obligation to exclude the land from ALF. It is permitted by the Act No. 252/1997 Coll. on Agriculture and the Decree No. 357/2013 Coll. on the Real Estate Cadaster ("cadastral decree").

The Act no. 252/1997 Coll. on Agriculture in the clause $2 \mathrm{e}$, section 3 , letter a) states that agricultural production means, inter alia, plant production, including the plants for technical and energy use on land owned, rented or used based on other legal purposes, or carried out without land. This definition was brought into effect on 10 November 2005.

On 1 March 2007 the cadastral decree no. 26/2007 Coll. came into effect and within it a new category of the use of the land belonging to ALF has been introduced, namely the plantation of energy woods. This enabled FGT to be planted on ALF soils (arable land, orchard, permanent grassland). Currently in power, the Decree No. 357/2013 Coll. on the Real Estate Cadaster in its Annex no. 2 still defines planting FGT for energy purposes as one of the possible ways of using a particular type of ALF land.

For the competent authorities and professional public, the obligation to exclude temporarily from ALF the land for the cultivation of FGT was abolished on 1 March 2007, within the cadastral decree amendment (Weger, Jobbíková, 2014). However, the decision-making practice of construction administrators and protection of ALF authorities at municipal level have not always respected it. Although the Protection of ALF Act does not literally state that exclusion of ALF land due to cultivation of FGT is not necessary, this rule indirectly results from the definition of the term "agricultural production" in the Agriculture Act and from the wording of the cadastral decree, which allows the use of "plantation of wood" on selected agricultural land. The professional public respects the common practice of not excluding the land from ALF for the cultivation of FGT, because they hold the opinion that cultivation of FGT is in fact agricultural land use and therefore the obligation to exclude the land would be absurd and ineffective (Hanák, Poláčková, 2012).

\section{Slovak Republic}

If FGT are planted for energy purposes on agricultural land, this is considered non-agricultural use of the agricultural land. According to the clause 17 of the Soil Protection Act, this is in fact temporary exclusion of the agricultural land. In compliance with the Soil Protection Act, temporary exclusion means a temporary change of the use of the agricultural land for a maximum of ten years, with the obligation to bring the land back to the original state by reclamation measures. If the cultivation of FGT exceeds the ten-year exclusion period, the user is obliged to apply for a new decision on the matter before the expiration of the original decision on temporary exclusion. 
The exclusion decision is issued by the Agricultural Land Protection Authority (hereinafter referred to as ALPA) in the circuit of which the agricultural land proposed for exclusion is located. To the application, the applicant is obliged to attach the project documentation, the balance sheet of the humus horizon, the reclamation project, the basic land identification data (cadastral record, copy of the cadastral map with designation of parcels proposed for exclusion, two copies of the geometric plan and ELEU confirmation), the statements of the parties and the respective bodies of the state administration and local authorities (for example, all non-native species of FGT can be planted with the consent of the nature conservation authority), the lawful territorial decision, other data necessary for judging on the nonagricultural purpose and calculating the levy for the entire extent of the exclusion. ALPA reviews the application and, if it finds that the principles of protection of the agricultural land are respected, it issues the exclusion decision, in which it states for what purposes the consent with the exclusion is issued, which parcels or cadastral areas are covered, lists of the documents on the basis of which the decision is issued, approval of the re-cultivation project, the balance sheet of the humus horizon, and states the conditions to ensure the protection of the agricultural land. Based on the exclusion decision the agricultural type of the land is changed and marked as the other type land.

\section{Request permission from Nature Conservation Authority}

\section{Czech Republic}

In compliance with the clause 5 section 4 and 5 of the Act no. 114/1992 Coll. on Nature and Landscape Protection, this obligation applies only to FGT that are supposed to be planted in sprout plantations and belong to geographically non-native species.

Legislation does not state any form of request permission from Nature Conservation Authority ("NCA") for authorizing the extent of geographically non-native plant species and their cross-breeds in the country. However, from the request it must be generally clear who is the addressee, who is the applicant and what they require.

The request should include contact details of the applicant and information on the implementation of the project, cadastral area, a proof of ownership (or a lease and owner's agreement on cultivation of FGT), the number of seedlings per hectare, planned period of life span of the plant and the method of the disposal of plantation.

The request for cultivation FGT must include (in attachment) the project intent, based on which the received request will objectively be assessed. The NCA reviews the project's compliance with the valid legislation and the specific conditions of the case such as the type of non-geographic plants and their cross-breeds, their quantity and planting area, the geographical conditions in the area and their impact on plants and animals in the area. The professional basis for the NCA judgment with respect to the Nature and Landscape Protection Act is a continuously updated list of plants suitable for cultivation and utilization as biomass for energy purposes from the point of view of risk elimination for nature and landscape conservation, elaborated by the Silva
Tarouca Research Institute for Landscape and Ornamental Horticulture. The result of the request review is the decision to authorize or reject it. The NCA decides on the location and conditions for establishing FGT plantations.

\section{Slovak Republic}

The cultivation of FGT in the conditions of the Slovak Republic must be consistent with the Soil Protection Act but also with the Act No. 543/2002 Coll. on Nature and Landscape Protection. Since all non-native species must be planted with the consent of the NCA, as mentioned above, the NCA statement forms an integral part of the application for temporary exclusion. The legislation does not prescribe any form of the request permission from the NCA or the request standpoint from that authority. That is why it is necessary to agree on the particular request procedure with the responsible NCA and its representatives.

In the clause 18a section 2 of the Act on Soil Protection the obligation of the person proposing the cultivation of the FGT on the agricultural land is stated along with the submission of the application for registration in the register of FGT areas managed by the District Authority, the Land and Forestry Department (further just DA).

In its attachment, the request for registration must have an extract from the property sheet or other document proving the ownership of the land or, if the founder is not the owner of the land, a document proving the lease relationship to the land or the consent of the owner of the land with its use for the purposes of FGT cultivation. Furthermore, the basic identification data of the area proposed for planting FGT should be attached, in particular a copy of the cadastral map, an extract from the property sheet from the register " $\mathrm{C}$ " of the cadaster or the identification of the parcel if the ownership right to the land is not registered on the parcel of register " $C$ ", the statement of the owner and the statement of the State Nature and Landscape Protection Authority or the geometric plan if the parcel is to be split.

The DA notifies about the registration of the area in the FGT areas register to municipalities and state administration authorities which could directly be affected by the FGT cultivation.

On the basis of the request for registration of FGT, the DA issues the certificate of registration of the FGT planting area for to the plant breeder, which then is sent to the Central Register of FGT areas maintained and updated by the soil service. The certificate includes a registration number for each separate FGT area, the start date and termination date of FGT cultivation, the size of the areas proposed for setting up the plantation based on cadastral identification data, the obligation to perform re-cultivation of the agricultural land at latest during the last year of FGT cultivation, the obligation to ensure the protection of the surrounding agricultural land against voluntary diffusion of plants from the FGT area.

For FGT cultivation, special maintenance and management of agricultural land are envisaged. The cultivation of special energy trees changes the characteristics of the agricultural land, because FGT are not only above the ground but a considerable mass of root system is created under ground, soil is compacted, water regime in soil is changed, etc. The Soil Protection Act therefore requires that the founder of the FGT plantations or their legal successor 
undertakes the reclamation of the agricultural land at the latest during the last year of planting FGT in compliance with the certificate issued by the DA.

\section{Changing agricultural crops to FGT crops}

\section{Czech Republic}

Changing agricultural culture to FGT culture relates only to the land registered in the Land Parcel Identification System (LPIS)1. For lands not registered in LPIS this is not required.

\section{Slovak Republic}

Due to the need for temporary exclusion of the agricultural land for the use of the FGT cultivation, the obligation to change the type of agricultural crops does not exist.

\section{Direct payments}

\section{Czech Republic}

Direct payments are primarily regulated by the Government Regulation of the Czech Republic no. 50/2015 Coll. on Laying Down Certain Conditions for Granting Direct Payments to Farmers.

Cultivation of FGT fulfils the conditions for unified payment for the agricultural land (SAPS) as well as for so called greening, i.e. payment for agricultural practices beneficial for climate and environment, and, possibly, payment for young farmers.

For the year 2016, the rates were set as follows:

- SAPS = 3,514 CZK ha-1 (approx. 134.75 €/ ha);

- greening = 1,928 CZK ha-1 (approx. $73.93 € /$ ha);

- for young farmers $=878 \mathrm{CZK} \mathrm{ha}^{-1}$ (approx. 33.67 $€ \mathrm{ha}^{-1}$ ).

Under the clause 2 of the Regulation, a natural or legal person who is an active farmer according to the EU Regulation no. $1307 / 2013$ and fulfils the conditions of an active farmer, is a farmer according to the Agriculture Act or is an organizational unit of the state and maintains the agricultural land registered in the Land Use Register and under user relations according to the Agriculture Act can apply for the direct payment. The request for direct payment to a farmer must be submitted to the State Agricultural and Intervention Fund by $15^{\text {th }}$ of May of the calendar year on the form issued by the Fund for the calendar year concerned. The other conditions are: the whole-year keeping cross-compliance conditions, declaration of all the agricultural land, which the applicant has registered in the LPIS by the date of submitting the request, which the applicant must have registered in the LPIS at the latest by 31 August of the calendar year. Their land must be of a minimum size 1 hectare and it has to be maintained and suitable for agricultural crops. In the case of FGT, the FGT must be stated in the list.

For greening it is necessary that ecological interest on the agricultural land exists. Under the clause 11 section 1, letter d) of the Regulation, the areas of FGT listed in the FGT list belong to the scope of ecological interest. The other

1 Based on European Commission Regulation no. 1307/2013 and $1122 / 2009$ on the registration and control of subsidies and payments of agricultural products from the EU an identification system of production units (LPIS) on agricultural land keeps the records. conditions are that FGT must be planted in a minimum number of 1,000 viable individual plants on the area of 1 hectare, including the handling space, and without the use of mineral fertilizers and plant protection products.

For payment of the grant to young farmers, the applicant, in addition to the general conditions, must comply with the requirements for young farmers stated in the EU Regulation no. $1307 / 2013$. This payment is granted for a maximum of 90 ha and for a maximum of 5 years.

Under the Article 50 section 2 of the EU Regulation No. $1307 / 2013$ the term "young farmers" is understood as natural persons who are to establish an agricultural enterprise as a company leaders for the first time or who have already set up such an enterprise within five years preceding the first request for the basic payment or the unified area payment scheme and who are under 40 years old in the year the application has been submitted.

The content requirements of the application for the direct payments on the agricultural land are set up in the clauses 4, 6 and 15 of the Regulation and in the Head II of the Chapter II of the EU Implementation Regulation No. $809 / 2014$. The application has to contain a clear identification of the beneficiary who has to meet all the requirements under the respective direct payment scheme, the list and the evaluation of all parts of the land blocks in compliance with the Agriculture Act enrolled in the Land Use Register by the applicant, the type of agricultural crops on all parts of the land blocks referred in the application, the applicant's declaration to obey the cross-compliance rules throughout the calendar year for all the agricultural land, the types of FGT planted on the land blocks and the calendar year of the FGT plantation or the year of the last cycle, if it has already been established. In the case of greening, it is in addition required that the application includes a list of parts of the land blocks and soil areas within the different land parts with FGT blocks and the drawing of relevant parts of land blocks with FGT plantation.

If the applicant submits the request after the deadline or fails to comply with the terms of the relevant Regulation, the amount of payments will be reduced or the request will be considered inadmissible. Direct payments for the applicants are also reduced due to violating financial discipline if the request for the direct payment exceeds $2,000 €$. In case of SAPS, additional rule is also applied: if the subsidy exceeds $150,000 €$, the payment to the applicant will be reduced by $5 \%$.

\section{Slovak Republic}

Direct payments are primarily regulated by the Government Regulation of the Slovak Republic no. 342/2014 Coll. on Laying Down Rules for the Granting Agricultural Support in connection with the schemes for decoupling direct payments.

Cultivation of FGT fulfils the conditions for unified payment for the agricultural land (SAPS) as well as for so called greening, i.e. payment for agricultural practices beneficial for climate and environment, and, possibly, payment for young farmers.

For the year 2016, the rates were set as follows:

$$
\begin{aligned}
& \text { - SAPS }=134.04 € \mathrm{ha}^{-1} ; \\
& \text { - greening }=71.17 € \mathrm{ha}^{-1} ; \\
& \text { - for young farmers }=60.41 € \mathrm{ha}^{-1} .
\end{aligned}
$$


Table 1

The list of FGT in Slovakia and Czechia

\begin{tabular}{|l|l|}
\hline Czech Republic & Slovak Republic \\
\hline - trembling poplar, collection cycle 8 years & - trembling poplar, collection cycle 8 years \\
- black poplar, collection cycle 10 years & - black poplar, collection cycle 10 years \\
- simona poplar, collection cycle 8 years & - robusta poplar, collection cycle 8 years \\
- cottonwood poplar, collection cycle 8 years & - simona poplar collection cycle 8 years \\
- maximowicz poplar, collection cycle 8 years & - cottonwood poplar, collection cycle 8 years \\
- balsam poplar, collection cycle 8 years & - maximowiczov poplar, collection cycle 8 years \\
- canadian poplar, collection cycle 5 years & - white willow, collection cycle 8 years \\
- jackii poplar, collection cycle 8 years & - basket willow, harvest cycle 5 years \\
- white willow, collection cycle 8 years & - sallow, collection cycle 5 years \\
- basket willow, harvest cycle 5 years & - daphne willow, collection cycle 5 years \\
- sallow, collection cycle 5 years & - common alder, collection cycle 8 years \\
- daphne willow, collection cycle 5 years & - gray alder, collection cycle 8 years \\
- common alder, collection cycle 8 years & - green alder, collection cycle 8 years \\
- gray alder, collection cycle 8 years & - common ash, collection cycle 8 years \\
- common ash, collection cycle 8 years & - silver birch, collection cycle 10 years \\
- common hazel, collection cycle 10 years & - European chestnut, collection cycle 10 years \\
& - European hornbeam, collection cycle 10 years \\
\hline
\end{tabular}

Source: the Ministry of Agriculture of the Czech Republic and the Ministry of Agriculture and Rural Development of the Slovak Republic

According to the clause 2 of the Regulation, the request for the direct payments may be submitted to the Agricultural Paying Agency by a person who maintains the agricultural area registered in the Register of Land Blocks on the territory of the Slovak Republic which reaches at least 1 hectare. This area may comprise several parts of the land blocks within the type of the agricultural area concerned of at least 0.3 ha maintained by one applicant, and it has to be at their disposal on 31 May of the year. It must have visibly marked and defined borders, if it is not bounded naturally, and FGT listed in the official list should be planted on it, including compliance with the maximum collection cycle.

Direct payments will be granted on the area of the agricultural area maintained by the applicant, which is eligible for support based on the recorded parts of the land blocks used for agricultural activities or predominantly used for agricultural activities.

The applicant must also meet the requirements of the active farmer and the cross compliance rules; i.e. to comply with the rules of good agricultural and environmental conditions, farming requirements and rules related to the environment, climate change and good condition of agricultural land, public health, animal and plant health and animal welfare.

For greening, it is necessary that ecological interest on the agricultural land exists. Under the clause 11, section 3, letter e) of the Regulation the areas of FGT listed in the FGT list belong to the scope of ecological interest.

For the payment to young farmers, the applicant, in addition to the general conditions, must comply with the requirements for young farmers stated in the EU Regulation no. $1307 / 2013$ and must have completed secondary or higher education or equivalent of the education in another Member State of the European Union with a focus on agriculture, food or veterinary medicine.

The Article 50 section 2 of the EU Regulation No. $1307 / 2013$, which defines the term "young farmers", is applicable in the Slovak Republic in the same way as well as in Czechia.
The content requirements of the application for the direct payments on the agricultural land are set up in the clauses 4, 6 and 15 of the Regulation and in the Head II of the Chapter II of the EU Implementation Regulation No. $809 / 2014$. The applicant has to submit the request from the date specified in the call announced by the Paying Agency at its website by 15 May of the year in the form of a unified application which contains a clear identification of the beneficiary meeting all the requirements under the direct payment scheme concerned and the annexes which are: the graphic material of the agricultural area, which is kept in the Register of the Land Blocks, the list of agricultural ground plots and the ways of their use, and the declaration of the submitted data veracity.

If the applicant submits the request after the deadline, the amount of payments will be reduced or the request will be considered inadmissible. Direct payments for the applicants are also reduced due to violating financial discipline if the request for the direct payment exceeds $2,000 €$. In case of SAPS, additional rule is also applied: if the subsidy exceeds $150,000 €$, the payment to the applicant will be reduced by $5 \%$.

\section{Non-repayable financial contribution}

\section{Czech Republic}

Under the Article 22 of the EU Regulation No. 1305/2013, the support is provided only for the costs of setting up the FGT plantation. The non-repayable financial contribution is funded from the Rural Development Program of the Czech Republic for 2014-2020, the measure Investments into Tangible Assets, sub-measure Support for Investments into Agricultural Enterprises.

The non-repayable financial contribution is granted on the basis of the requests submitted to the State Agricultural and Intervention Fund on the basis of the published calls.

The calls for applications and requests are published on a regular basis, according to the schedule announced for the calendar year. Due to the regular periodicity, the budget of the funds is lower. The terms are always stated in a specific 
call and changed from one call to the following one. The contribution is awarded to the applicants on the basis of a point system based on preferential criteria.

For the next call for requests submission, which will run from 10 to 30 October 2017, no specific preferential criteria have been identified for FGT and the general criteria for plant production will be applied. For the FGT there is no specific financial budget allocated from the total amount of the funds in the value of $1,137,168,000$ CZK (approx. $43,600,000 €)$.

\section{Slovak Republic}

Under the Article 22 of the EU Regulation No. 1305/2013, the support is provided only for the costs of setting up the FGT plantation. The non-repayable financial contribution is provided from the Rural Development Program of the Slovak Republic for 2014-2020, the measure Investments into Tangible Assets, sub-measure Support for Investments into Agricultural Enterprises.

The non-repayable financial contribution is granted on the basis of the requests submitted to the Agricultural Payments Agency on the basis of the published calls.

The calls for applications are published irregularly. Due to irregular periodicity, the budget of the funds is higher. The terms are always stated in a specific call and changed from one call to the following one. The contribution is awarded to the applicants on the basis of a point system based on preferential criteria.

In the last call for requests submission, which was run from 12 June 2015 to 30 October 2015, there had been set specific preferential criteria applicable for biomass, establishing FGT and other permanent energy crops, investments related to energy use of biomass in connection with investments into other areas. For FGT the financial budget of 1,500,000 € was allocated from the total amount of $147,752,000 €$.

In the Slovak Republic, as well as in the Czech Republic, FGT are cultivated on the agricultural land and not on plots intended for forest purposes. Plots intended for forest purposes are the ones used for growing forest stands so that the forests are capable of performing permanently, evenly and continuously as many forest functions as possible. For

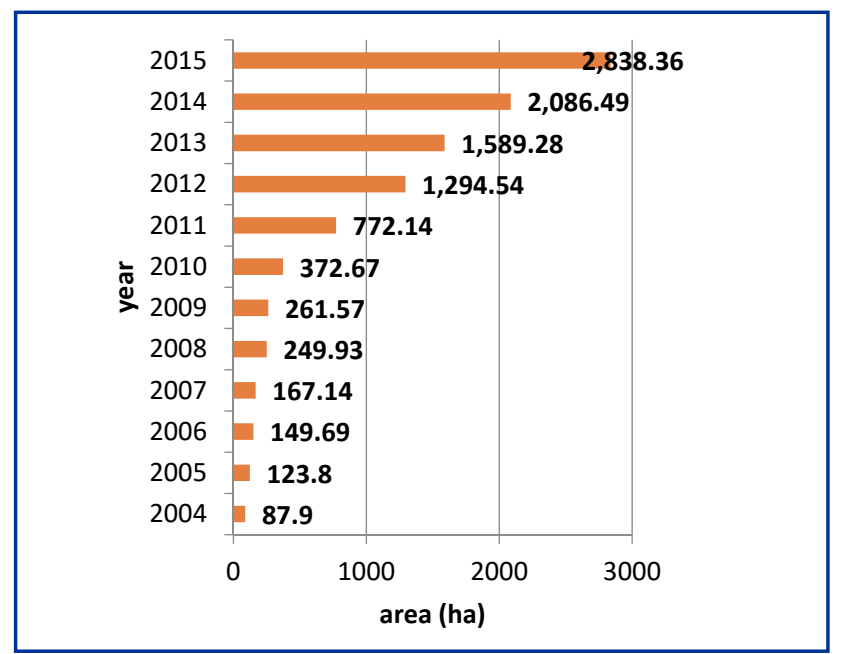

Figure 1 Trend of the area of FGT from 2004 to 2015 in the Czech Republic

Source: Land Register LPIS

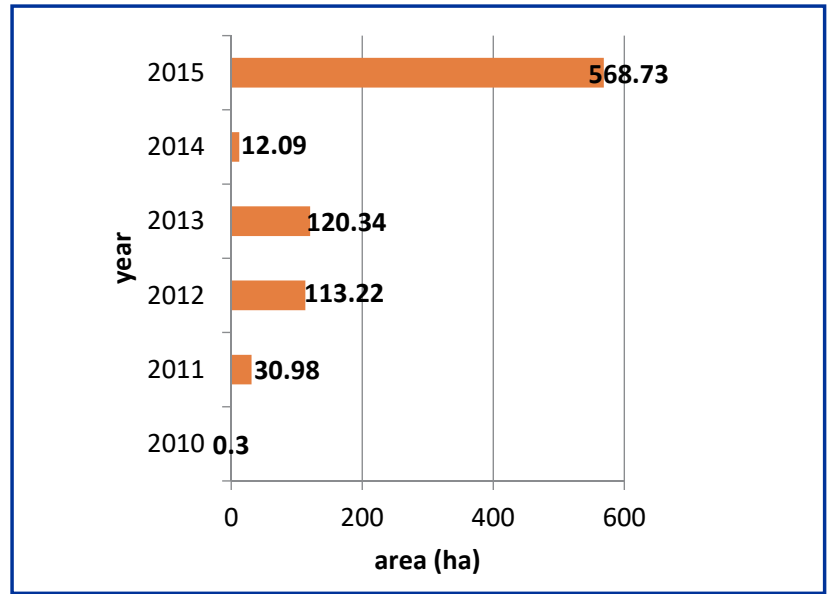

Figure 2 Trend of the area of FGT from 2010 to 2015 in the Slovak Republic

Source: Electronic Yearbook of Soil Service

example, in the forest land, the rotation period of poplar lignite cultures ranges from 15 to 30 years. But the sprout plantations are established mainly on poorly fertile agricultural soils with a rotation period of 3 to 7 years, which can be repeated several times without the need for new planting.

\section{Conclusions}

Properly set legislative conditions are equally important as a well-set support policy. In the Slovak Republic, the area of the FGT sprout plantations has recently been growing, with the exception of the decline in 2014, which was caused by the change in the law on soil protection (see Figure 1). However, after adjusting to the new conditions for the FGT, their areas have increased. Applicants in Slovakia must submit a request for temporary exclusion of the agricultural land and an application for registration in FGT areas, and, in addition, nonnative species must be planted with the consent of the NCA.

The growing area of the FGT plantations in the Czech Republic has been steadily increasing since 2004 (see Figure 2). At the time when the land had to be excluded from the ALF, there was a subsidy scheme for establishing FGT plantations and from the year 2007, when the obligation to exclude the land from the ALF was abolished, on the contrary, subsidies for establishing FGT plantations were terminated. Thus, from 2007, the applicants in the Czech Republic do not have to apply for temporary exclusion of agricultural land, but in case of non-native types of FGT, there is an obligation to apply for their permission from the NCA.

The differences between the two countries in terms of the legal conditions of growing FGT are as follows:

- in Slovakia, there is an obligation to apply for temporary exclusion of the agricultural land and in Czech Republic there is no such obligation;

- another difference is the length of the maximum period the agricultural land can be used for FGT cultivation - in Slovakia it is 20 years and in the Czech Republic it is 30 .

Similarly for both countries, there is an obligation to have the permission from the NCA to plant non-native types of FGT. Also, both countries have in common the condition that it is forbidden to cultivate FGT on the highest quality agricultural land and in both countries there are no requirements for the form of the application to the NCA. 
The legislative conditions can be considered liberal because there are minimum cultivation restrictions and there are no other standards and permissions. However, it should be mentioned that the rationale for establishing FGT areas is not only legislative, but also biological, economic and political.

The FGT support system in both countries is set up in compliance with the EU regulations. The direct payments are set in both countries in governmental regulations. Conditions for the direct payments SAPS and greening are almost the same. The only difference in the direct payments is with regard to the payments for young farmers. In Slovakia, there is an obligation to have the relevant education to be granted this direct payment; the amount of granted payments is almost twice as high compared to the Czech Republic and without area and time limitation.

Non-repayable financial contributions are funded in both countries from the rural development program. However, despite the similar conditions for non-repayable financial contributions, it should be noted that in the Czech Republic, the FGT support system in the form of subsidies is more detailed and more systematic, which has a big impact especially on applicants who, in such a way, have more precisely defined rules and whose expectations will be met more likely.

The problems regarding the cultivation of FGT, not only in Slovakia and Czechia, but also in other EU countries, are connected mainly with the availability and accessibility of financial support. The need for greater financial support is an issue that needs to be addressed in order to increase the FGT market. Another problem is that there is a lack of awareness regarding the potential positive ecological impacts of FGT (Lindegaard et al., 2016).

To solve the above mentioned problems, and especially to make the accessibility of financial support easier for farmers growing FGT, the list of FGT eligible for direct payments should be expanded. With regard to the non-repayable financial contributions, a budget only to support cultivation of FGT should be raised as in the last calls for applications the support of FGT was funded from the budged for financial support of the whole plant production in the Czech Republic and for financial support of biomass and energy crops in Slovakia. The producers of heat or combination of heat and power from FGT should be rewarded with some benefits for the use and consumption of FGT.

The development and enlargement of FGT sprout plantations is affected by the combination of various positive aspects, among which legislative, biological, economic, social and political aspects can be found. The main aspects are economic, because many owners are looking at the profit they can get from their ownership of the land (Janků et al. 2016). However, it is also necessary to take into consideration the limits and risks of planting FGT. Among the key conditions for the future of planting FGT should be mentioned such aspects as: the creation and maintenance of favourable aspects and the prevention of potential risks of FGT cultivation, appropriately adjusted subsidy policy and further research in the field, for example, aimed at increasing yields and pest resistance.

\section{References}

Act no. 114/1992 Coll. on Nature and Landscape Protection.

Act no. 220/2004 Coll. on the Protection and Use of Agricultural Land. Act no. 252/1997 Coll. on Agriculture.

Act no. 334/1992 Coll. on the Protection of Agricultural Land Fund. Act no. 543/2002 Coll. on Nature and Landscape Protection.

Agricultural Payments Agency. Available online: http://www.apa.sk/ BIOMASS Use Action Plan for 2008-2013. Available online: http:// www.mpsr.sk/sk/index.php?navID=2\&navID2=2\&sID=26\&id=1214 COMMISSION implementing regulation (EU) No 809/2014 of 17 July 2014 laying down rules for the application of Regulation (EU) No 1306/2013 of the European Parliament and of the Council with regard to the integrated administration and control system, rural development measures and cross compliance.

DECREE No. 26/2007 Coll. on Cadastre of Real Estates (Cadastral Decree).

FARMER eAGRI Portal. Land Register LPIS. Dostupné online: http:// eagri.cz/public/web/mze/farmar/LPIS/

GOVERNMENT Regulation of the Czech Republic no. 50/2015 Coll. on laying down certain conditions for granting direct payments to farmers.

GOVERNMENT Regulation of the Slovak Republic no. 342/2014 Coll. on laying down rules for the granting of agricultural support in connection with the schemes for decoupling direct payments.

HANÁK, J. - POLÁČKOVÁ, M. 2012. Pěstování rychle rostoucích dřevin. Available online: https://www.law.muni.cz/sborniky/dny_ prava_2012/files/pozemek/PolackovaMarie_HanakJakub.pdf

JANKUீ, J. et al. 2016. Land Use Analysis in Terms of Farmland Protection in the Czech Republic. Available online: http://www. agriculturejournals.cz/publicFiles/173200.pdf

KOTRLA, M. - PRČíK, M. 2012. Možnosti využitia pestovania energetických rastlín na pol'nohospodársky nevyužívanej pôde v podmienkach Slovenska. Available online: http://www.slpk.sk/ eldo/2012/zborniky/017-12/kotrla_prcik.pdf

LINDEGAARD, K. N. et al. 2016. Short rotation plantations policy history in Europe: lessons from the past and recommendations for the future. Available online: https://www.ncbi.nlm.nih.gov/pmc/ articles/PMC5111424/

MARIŠOVÁ et al. 2015. Legislation of Renewable Energy Sources in Slovakia. Available online: https://www.degruyter.com/down loadpdf/j/eual.2015.4.issue-2/eual-2015-0011/eual-2015-0011.pdf

PETZOLD, R. et al. 2014. Linking biomass production in short rotation coppice with soil protection and nature conservation. Available online: http://www.sisef.it/iforest/contents/?id=ifor1168-007

REGULATION (EU) No. 1307/2013 of the European Parliament and of the Council establishing rules for direct payments to farmers under support schemes within the framework of the common agricultural policy.

SILVA TAROUCA Research Institute for Landscape and Ornamental Horticulture. 2016. Subsidies for FGT plantations. Available online: http://www.vukoz.cz/index.php/rychle-rostouci-dreviny/ dotace-pro-rrd

SOIL Science and Conservation Research Institute. Electronic Yearbook of Soil Service. Available online: https://podnemapy. vupop.sk/?q=zabery

STATE Agricultural and Intervention Fund. Available online: https:// www.szif.cz/cs/

WEGER, J. - JOBBÍKOVÁ, J. 2014. Rozvíjející se trh s rychle rostoucími dřevinami - biologické, ekonomické a legislativní aspekty. Available online: http://www.vukoz.cz/dokumenty/isoze/ prezentace/Rozvijejici\%20se\%20trh\%20RRD\%2020\%20let.pdf 